УДК 615.015.32:37.091.214.18:303.442.3

\title{
АНАЛІЗ ТЕМАТИЧНОЇ СТРУКТУРИ НАВЧАЛЬНОЇ ДИСЦИПЛІНИ “ОСНОВИ ГОМЕОПАТІї”
}

\author{
Л. П. Гуцол, А. В. Горілик* \\ Вінницький національний медичний університет імені М. I. Пирогова, \\ *Львівський національний медичний університет імені Данила Галищького

\section{THE ANALYSIS OF THE THEMATIC STRUCTURE OF THE EDUCATIONAL DISCIPLINE "FUNDAMENTALS OF HOMEOPATHY"} \\ L. P. Hutsol, A. V. Horilyk* \\ Vinnytsia National Medical University by M. I. Pyrohov, \\ ${ }^{*}$ Lviv National Medical University by Danylo Halytskyi
}

\begin{abstract}
За допомогою оригінальної методики проведено оцінювання структури тематичного плану курсу за вибором “Основи гомеопатії” для студентів вищих медичних навчальних закладів III-IV рівнів акредитації. Запропоновано оптимізувати розподіл обсягу навчального часу відповідно до результатів анкетного опитування лікарів-інтернів.
\end{abstract}

The evaluation of the thematic plan structure of theelective course "Fundamentals of Homeopathy" for the students of III- IV accreditation levels higher medical educational establishments was conducted with the original method. It was proposed to optimize the distribution of study time according to the questionnaire survey of the interns.

Вступ. Гомеопатія є дієвою системою лікування, яка ефективно використовується при дисфункціях окремих систем і органів та підвищує функціональні можливості організму. Про це свідчить багатий історичний досвід іï застосування, а також сучасні наукові розробки [1]. Слід зазначити, що за останні роки відмічено зростання попиту серед лікарів іпровізорів у навчанні гомеопатичних принципів [2]. На теперішньому етапі розвитку гомеопатичного методу дуже важливим $€$ формування правильних уявлень про його можливості, місце в клінічній медицині, а також шляхи інтеграції з іншими видами лікування і профілактики захворювань й медичної реабілітації.

Для студентів медичних вузів України починаючи з 1994 року велося викладання елективного курсу 3 гомеопатії з використанням відповідної програми “Основи сучасної гомеопатії'. У зв'язку з набутим навчально-методичним досвідом та появою нових наукових даних у 2006 році з урахуванням стандартів кредитно-модульної системи було розпочато оптимізацію програми з основ гомеопатії [1]. Нову програму навчальної дисципліни “Основи гомеопатії” (курс за вибором) для студентів вищих медичних навчальних закладів III-IV рівнів акредитації було затверджено у 2008 році [3].

Вважаємо, що через 5 років після створення програми навчальної дисципліни назріла необхідність у (с Л. П. Гуцол, А. В. Горілик моніторингу актуальності її тематик та відповідності структури сучасним тенденціям медичної практики.

Основна частина. Метою нашої роботи було проектування оптимального розподілу обсягу академічних годин між темами програми навчальної дисципліни “Основи гомеопатії” (курс за вибором) для студентів вищих медичних навчальних закладів III-IV рівнів акредитації на підставі результатів експертизи лікарями-інтернами цієї освітньої програми.

При проведенні дослідження використано методи анкетного опитування і статистичного аналізу даних. Об' єктом дослідження стала тематика дисципліни “Основи гомеопатіï” за навчальним планом для студентів вищих медичних навчальних закладів III-IV рівнів акредитації за спеціальностями 7.110101 "Лікувальна справа", 7.110104 "Педіатрія" та 7.110105 "Медико-профілактична справа".

В основі дослідження використано методику оцінювання структури тематичних планів фармацевтичних освітніх дисциплін [4], суть якої полягає у залученні випускників та практикуючих фахівців до експертизи навчальних планів на предмет актуальності для практичної діяльності. Оцінка проводиться за такою шкалою: "5" - дуже важливо, “4” - важливо, “3” - частково важливо, "2" - скоріше не важливо та “1” - зовсім не важливо. 
Позаяк із назви теми респондентам інколи трудно усвідомити іiі зміст, було запропоновано удосконалити вказану методику шляхом оцінювання не тем, а ключових запитань, що вивчаються у кожній темі. Таким чином була сформована анкета, що передбачала оцінювання від трьох до десяти ключових програмних запитань до кожної теми.

Дизайн дослідження характеризувався такими параметрами.

1. Місце збору даних: м. Вінниця - Вінницький національний медичний університет імені М. І. Пирогова.

2. Період збору даних: червень 2013 року.

3. Отримана 91 анкета, з яких відібрано та опрацьовано 83 якісно заповнених анкети.

Серед опитаних були: лікарі-інтерни першого року навчання за спеціальністю “Дерматовенерологія” (9 осіб), а також лікарі-інтерни другого року навчання за такими спеціальностями: загальна практика сімейна медицина (27 осіб), внутрішні хвороби (25 осіб), педіатрія (7 осіб), офтальмологія (5 осіб), хірургія (6 осіб), урологія (2 особи), анестезіологія та оториноларингологія (по 1 особі).

Усі опитані лікарі-інтерни вивчали дисципліну “Оcнови гомеопатіи” на 4 курсі Вінницького національного медичного університету імені М. І. Пирогова.

4. Оптимальний обсяг вибірки визначали за формулою безповторного відбору А. Н. Колмогорова та співавторів [5]:

Таблиця 1. Результати оцінювання важливості вивчення ключових запитань дисципліни за вибором “Основи гомеопатіі"

$$
n \times p>4,
$$

де $n$ - число спостережень, $p$ - імовірність помилки.

Позаяк в соціологічних дослідженнях допускається помилка $p=0,05$, то має бути щонайменше 81 спостереження. Таким чином, число опитаних фахівців у процесі дослідження можна вважати достатньо репрезентативним.

Для аналізу одержаних результатів розраховували середні значення $(\bar{x})$ та похибку середнього $(m)$, а для оцінки ступеня узгодженості думок респондентів - коефіцієнт варіації (v) за формулою:

$$
v=(\sigma / \bar{x}) \text {, }
$$

де $\sigma$ - стандартне відхилення, $\bar{x}$ - середнє значення.

Вважали, що сукупність однорідна і середня величина в ній є типовою, якщо коефіцієнт варіації не перевищує $33 \%$ [6].

При ранжуванні ключових запитань однаковим значенням їхніх оцінок присвоюється ранг, що дорівнював середньому числу позицій запитань у порядку зростання величини.

Усі розрахунки проводилися за допомогою надбудови "Пакет аналізу” для Microsoft Excel.

Як видно з даних таблиці 1, розраховані коефіцієнти варіації в оцінюванні ключових запитань знаходяться в інтервалі від 18,3 до 34,5 \%. При цьому лише для двох 3 них (1.5 та 1.6) величини коефіцієнтів варіації оцінок є незначно вищими за $33 \%$, тобто для абсолютної більшості ключових запитань існує узго-

\begin{tabular}{|c|c|c|c|}
\hline Ранг & Ключові запитання* & $\bar{x} \pm m$ & $v, \%$ \\
\hline 1 & 2 & 3 & 4 \\
\hline \multicolumn{4}{|c|}{ Оичіночний інтервал 1 “дуже важливо - важливо” } \\
\hline 1 & 4.1. Симптоми, їх використання і значення в гомеопатії & $4,20 \pm 0,09$ & 19,2 \\
\hline 2 & $\begin{array}{l}9.3 \text { Комплексні гомеопатичні препарати для використання в дерматології, що } \\
\text { зареєстровані в Україні }\end{array}$ & $4,17 \pm 0,09$ & 19,4 \\
\hline 3 & $\begin{array}{l}\text { 4.3. Локалізація патологічного процесу, іiї значення для призначення } \\
\text { гомеопатичного препарату }\end{array}$ & $4,16 \pm 0,10$ & 21,1 \\
\hline 4 & $\begin{array}{l}\text { 12.1. Індивідуальні симптоми як показання для гомеопатичних препаратів на } \\
\text { прикладі лікування хворих з вегетативною дистонією невротичного генезу }\end{array}$ & $4,12 \pm 0,08$ & 18,3 \\
\hline 5 & $\begin{array}{l}\text { 4.6. Клінічне обстеження. Гомеопатичний анамнез: методологія його збору. } \\
\text { Пошук загальних, локальних симптомів та модальностей }\end{array}$ & $4,11 \pm 0,10$ & 21,2 \\
\hline 7 & $\begin{array}{l}\text { 5.7. Поняття гомеопатичної дози. Критерії вибору потенції гомеопатичного } \\
\text { препарату }\end{array}$ & $4,10 \pm 0,09$ & 21,1 \\
\hline 7 & $\begin{array}{l}\text { 8.1. Індивідуальні симптоми як показання для гомеопатичних препаратів на } \\
\text { прикладі лікування хворих з ГРВІ }\end{array}$ & $4,10 \pm 0,09$ & 19,3 \\
\hline 7 & $\begin{array}{l}\text { 9.4. Основні складові, принципи формування комплексних препаратів для } \\
\text { лікування атопічного дерматиту }\end{array}$ & $4,10 \pm 0,09$ & 19,3 \\
\hline 9 & 4.2. Етіологічні фактори, їх значення для медикаментозного діагнозу & $4,09 \pm 0,10$ & 21,5 \\
\hline 10 & $\begin{array}{l}\text { 13.3. Основні складові, принципи формування комплексних препаратів для } \\
\text { лікування дітей }\end{array}$ & $4,08 \pm 0,10$ & 23,0 \\
\hline
\end{tabular}
дженість думок респондентів. 
Продовження табл. 1

\begin{tabular}{|c|c|c|c|}
\hline 1 & 2 & 3 & 4 \\
\hline 12 & 2.5. Медикаментозне загострення та його типи & $4,07 \pm 0,09$ & 21,1 \\
\hline 12 & $\begin{array}{l}\text { 11.2. Комплексні гомеопатичні препарати для лікування вегетативної дистонії, } \\
\text { що зареєстровані в Україні }\end{array}$ & $4,07 \pm 0,09$ & 20,6 \\
\hline 12 & 14.2. Огляд основних гомеопатичних монопрепаратів для педіатричної практики & $4,07 \pm 0,11$ & 23,9 \\
\hline 14 & $\begin{array}{l}\text { 7.2. Комплексні гомеопатичні препарати для лікування ГРВІ, що зареєстровані в } \\
\text { Україні }\end{array}$ & $4,06 \pm 0,09$ & 19,7 \\
\hline 15 & $\begin{array}{l}\text { 13.2. Комплексні гомеопатичні препарати для педіатричної практики, що } \\
\text { зареєстровані в Україні }\end{array}$ & $4,05 \pm 0,11$ & 24,4 \\
\hline 16,5 & $\begin{array}{l}\text { 4.9. Роль фізикального та інструментально-лабораторного обстеження для } \\
\text { призначення гомеопатичного препарату }\end{array}$ & $4,04 \pm 0,10$ & 23,2 \\
\hline 16,5 & 9.2. Клінічна характеристика атопічного дерматиту & $4,04 \pm 0,09$ & 19,6 \\
\hline 18,5 & $\begin{array}{l}\text { 11.3. Основні складові, принципи формування комплексних препаратів для } \\
\text { лікування вегетативної дистонії невротичного генезу }\end{array}$ & $4,02 \pm 0,09$ & 20,9 \\
\hline 18,5 & $\begin{array}{l}\text { 14.1. Індивідуальні симптоми як показання для гомеопатичних препаратів на } \\
\text { прикладі лікування дітей }\end{array}$ & $4,02 \pm 0,10$ & 23,0 \\
\hline 20 & 5.5. Поняття гомеопатичного антидоту & $4,00 \pm 0,11$ & 24,1 \\
\hline \multicolumn{4}{|c|}{ Оиіночний інтервал 2 “важливо - частково важллио” } \\
\hline 21 & 13.1. Функціональні захворювання в педіатрії & $3,99 \pm 0,10$ & 23,7 \\
\hline 22 & $\begin{array}{l}\text { 7.3. Основні складові, принципи формування комплексних препаратів для } \\
\text { лікування ГРВІ }\end{array}$ & $3,98 \pm 0,10$ & 22,2 \\
\hline 23 & 2.4. Поняття про медикаментозний патогенез та медика & $3,97 \pm 0,10$ & 22,4 \\
\hline 25 & $\begin{array}{l}\text { 10.2. Огляд основних гомеопатичних монопрепаратів для лікування алергічних } \\
\text { захворювань шкіри }\end{array}$ & $3,96 \pm 0,09$ & 21,5 \\
\hline 25 & 11.1. Синдром вегетативної дистонії та його основні клінічні прояви & $3,96 \pm 0,10$ & 23,1 \\
\hline 25 & 14.3. Реперторизація основних індивідуальних симптомів & $3,96 \pm 0,11$ & 25,4 \\
\hline 27,5 & 8.2. Огляд основних гомеопатичних монопрепаратів для лік & $3,95 \pm 0,11$ & 24,6 \\
\hline 27,5 & 9.1. Визначення та класифікація алергічних реакцій & $3,95 \pm 0,10$ & 22,0 \\
\hline 29 & 5.3. Визначення медикаментозного типу пацієнта & $3,94 \pm 0,10$ & 22,5 \\
\hline 30,5 & 3.6. Правила виписування гомеопатичного рецепта & $3,93 \pm 0,12$ & 26,9 \\
\hline 30,5 & $\begin{array}{l}\text { 12.2. Огляд основних гомеопатичних монопрепаратів для лікування вегетативної } \\
\text { дистонії невротичного генезу }\end{array}$ & $3,93 \pm 0,08$ & 19,5 \\
\hline 32 & 7.1. Найчастіші гострі респіраторні вірусні інфекції & $3,91 \pm 0,10$ & 23,5 \\
\hline 33 & $\begin{array}{l}\text { 6.4. Особливості дії антигомотоксичних препаратів, } \\
\text { протипоказання до їх застосування }\end{array}$ & $3,90 \pm 0,10$ & 24,2 \\
\hline 34 & $\begin{array}{l}\text { 10.1. Індивідуальні симптоми як показання для гомеопатичних препаратів на } \\
\text { прикладі лікування хворих з алергічними станами }\end{array}$ & $3,88 \pm 0,09$ & 21,6 \\
\hline 35 & 4.7. Значення спадковості та анамнезу життя для призначення лікування & $3,87 \pm 0,11$ & 26,3 \\
\hline 36 & 1.4. Сучасне визначення гомеопатії. Принципи гомеопатії & $3,86 \pm 0,10$ & 23,7 \\
\hline 37 & 2.3. Правила проведення випробувань гомеопатичних ліків & $3,85 \pm 0,10$ & 24,5 \\
\hline 39,5 & $\begin{array}{l}\text { 5.1. Конституціональний та синдромальний підходи до вибору гомеопатичного } \\
\text { препарату }\end{array}$ & $3,84 \pm 0,10$ & 23,2 \\
\hline 39,5 & $\begin{array}{l}\text { 5.2. Принципи формування гомеопатичних комплексних препаратів. Поняття } \\
\text { про випробувані показання для лікарських засобів }\end{array}$ & $3,84 \pm 0,08$ & 19,7 \\
\hline 39,5 & $\begin{array}{l}\text { 5.6. Гомеопатичний Repertorium, його будова. Реперторіуми Дж. Т. Кента, } \\
\text { Synthesis. Вибір препарату за допомогою Repertorium. Ранжування симптомів за } \\
\text { точністю і цінністю }\end{array}$ & $3,84 \pm 0,12$ & 27,6 \\
\hline 39,5 & 12.3. Реперторизація основних індивідуальних симптомів & $3,84 \pm 0,08$ & 19,2 \\
\hline 43 & $\begin{array}{l}\text { 5.4. Гомеопатична Materia medica, iï будова. Вибір гомеопатичного препарату за } \\
\text { допомогою Materia medica }\end{array}$ & $3,83 \pm 0,11$ & 25,6 \\
\hline 43 & $\begin{array}{l}\text { 6.1. Використання принципів ізопатії в імунопрофілактиці, специфічній } \\
\text { десенсибілізації }\end{array}$ & $3,83 \pm 0,10$ & 24,7 \\
\hline
\end{tabular}


Продовження табл. 1

\begin{tabular}{|c|c|c|c|}
\hline 1 & 2 & 3 & 4 \\
\hline 43 & 8.3. Реперторизація основних індивідуальних симптомів & $3,83 \pm 0,09$ & 22,0 \\
\hline 45 & $\begin{array}{l}\text { 2.2. Джерела знань про гомеопатичні засоби: випробування гомеопатичних ліків } \\
\text { на здорових, дані токси кології та фармакології, спостереження за вживанням } \\
\text { гомеопатичних ліків хворими, зас тосування гомеопатії у ветеринарії }\end{array}$ & $3,78 \pm 0,09$ & 22,6 \\
\hline 46,5 & 6.2. Основні принципи і наукове обгрунтування гомотокси кології & $3,75 \pm 0,10$ & 23,5 \\
\hline 46,5 & 10.3. Репер торизація основних індивідуальних симптомів & $3,75 \pm 0,10$ & 24,0 \\
\hline 48 & 2.1. Сучасне наукове обгрунтування гомеопатії & $3,73 \pm 0,10$ & 25,3 \\
\hline 49 & 1.7. Роль та місце гомеопатії в сучасній лікарській практиці & $3,68 \pm 0,11$ & 26,9 \\
\hline 50 & 4.4. Характер відчуттів та їх роль у встановленні діагнозу & $3,67 \pm 0,10$ & 25,0 \\
\hline 51 & 4.5. Модальності (умови виникнення) та їх значення для вибору препарату & $3,66 \pm 0,11$ & 26,2 \\
\hline 52,5 & $\begin{array}{l}\text { 3.4. Поняття по тенціювання (динамізації); низьких, середніх і висо ких потенцій. } \\
\text { Шкали гомеопатичних розве день }\end{array}$ & $3,63 \pm 0,12$ & 30,7 \\
\hline 52,5 & 4.8. Гомеопатична історія хвороби & $3,63 \pm 0,12$ & 29,8 \\
\hline 54,5 & 3.1. По хо дження гомеопатичних ліків & $3,61 \pm 0,11$ & 27,9 \\
\hline 54,5 & 4.10. Оцінка динам іки стану пацієнта за законами К. Герінга & $3,61 \pm 0,12$ & 30,1 \\
\hline 56 & 3.3. Визначення гомеопатичного лікарського засобу, материнської тинктури & $3,59 \pm 0,12$ & 29,5 \\
\hline 57 & $\begin{array}{l}\text { 1.2. Саногенетичні процеси, їх складові частини (реституція, регенерація, } \\
\text { компенсація, діяльність імунної сис теми, мікроциркуляція). Можливості впливу } \\
\text { на них у клінічних умовах }\end{array}$ & $3,57 \pm 0,11$ & 27,5 \\
\hline 58 & $\begin{array}{l}\text { 1.1. Основні теоретичні та мето дичні аспекти сучасної немедикаментозної } \\
\text { терапії і реабілітації }\end{array}$ & $3,55 \pm 0,11$ & 27,9 \\
\hline 59 & $\begin{array}{l}\text { 3.5. Методи виготовлення гомеопатичних потенцій за С. Ганеманном і } \\
\text { С. Корсаковим }\end{array}$ & $3,52 \pm 0,11$ & 28,2 \\
\hline 60 & 6.3. Фази захворювання за Г. Реккевегом & $3,51 \pm 0,11$ & 29,3 \\
\hline 61 & $\begin{array}{l}\text { 1.3. Поняття про мето ди комплементарної (підсилюючої, доповнюючої) } \\
\text { медицини. Визначення гомеопатії як складової час тини комплементарної } \\
\text { медицини }\end{array}$ & $3,46 \pm 0,10$ & 27,6 \\
\hline 62 & 3.2. Фармакопея В. Швабе & $3,35 \pm 0,12$ & 32,2 \\
\hline 63 & 1.5. С. Ганеманн - засновник гомеопатії. Основні праці С. Ганеманна & $3,17 \pm 0,12$ & 33,9 \\
\hline 64 & 1.6. Основні історичні етапи розвитку гомеопатії & $3,05 \pm 0,12$ & 34,5 \\
\hline
\end{tabular}

* - число поряд із ключовим питанням вказує його приналежність до конкретної теми і порядковий номер питання в цій темі.

Весь перелік ключових запитань розподілено на два оціночні інтервали: “дуже важливо - важливо” (20 запитань) i “важливо - частково важливо” (44 запитання). Варто зазначити, що до першого оціночного інтервалу попали ключові запитання десяти з чотирнадцяти тем, а саме 3 другої, четвертої, п’ятої, сьомої дев' ятої, одинадцятої - чотирнадцятої тем. Найвище оцінені ключові запитання, що стосуються вивчення симптомів, їх використання і значення в гомеопатії (ранг 1), комплексні гомеопатичні препарати для використання в дерматології (ранг 2), локалізація патологічного процесу та іiі значення для призначення гомеопатичного препарату (ранг 3), індивідуальні симптоми як показання для гомеопатичних препаратів (ранг 4), клінічне обстеження, методологія збору гомеопатичного анамнезу, пошук загальних, локальних симптомів та модульностей (ранг 5) та інші.

При цьому шкала важливості запитання "реперторизація основних індивідуальних симптомів” за те- мами має такий вигляд: 14 (ранг 25), 12 (ранг 39,5), 10 (ранг 43) та 8 (ранг 46,5).

Суму оцінок ключових запитань за темами було використано для обрахунку частки обсягу годин кожної теми за важливістю для практичної діяльності майбутнього лікаря (табл. 2). На основі цих даних було здійснено проектування розподілу обсягу навчальних годин за темами.

Як видно з даних таблиці 2, вагомість вивчення різних тем за результатами анкетного опитування відрізняється. Саме тому, на нашу думку, доцільним $\epsilon$ коригування розподілу навчальних годин за темами. Так, час, передбачений для вивчення тем № 1 i 3, слід збільшити 33 до 4 годин, а тем № 4 і 5 - до 6 i 5 годин відповідно. При цьому кількість академічних годин, призначених для вивчення тем № 6, 7, 8, 10, 11, 12 i 13, варто зменшити до 2 годин. Обсяг годин, відведених для вивчення решти тем, необхідно залишити без змін. 
Таблиця 2. Проектування обсягу годин за темами навчального плану дисципліни за вибором “Основи гомеопатіі”

\begin{tabular}{|c|c|c|c|c|}
\hline Тема & $\begin{array}{c}\text { Сума оцінок } \\
\text { ключових } \\
\text { питань } \\
\end{array}$ & $\begin{array}{c}\text { Частка, } \\
\%\end{array}$ & $\begin{array}{l}\text { Години } \\
\text { за } \\
\text { планом } \\
\end{array}$ & $\begin{array}{l}\text { Пропоно- } \\
\text { вана } \\
\text { к-сть годин } \\
\end{array}$ \\
\hline \multicolumn{5}{|c|}{ Змістовий модуль 1. Загальна гомеопатія } \\
\hline $\begin{array}{l}\text { 1. Визначення гомеопатії, iї роль та місце в сучасній } \\
\text { медицині. Історія розвитку, організація та загальні питання } \\
\text { гомеопатії }\end{array}$ & 24,34 & 9,9 & 3 & 4 \\
\hline $\begin{array}{l}\text { 2. Наукове обгрунтування гомеопатії. Основні напрямки } \\
\text { наукових досліджень у гомеопатії }\end{array}$ & 19,42 & 7,9 & 3 & 3 \\
\hline $\begin{array}{l}\text { 3. Гомеопатична фармакопея. Походження і виготовлення } \\
\text { гомеопатичних ліків }\end{array}$ & 21,63 & 8,8 & 3 & 4 \\
\hline $\begin{array}{l}\text { 4. Методологія гомеопатичного обстеження. Гомеопатична } \\
\text { семіотика }\end{array}$ & 39,03 & 15,8 & 3 & 6 \\
\hline $\begin{array}{l}\text { 5. Конституціональний і синдромальний підходи до вибору } \\
\text { гомеопатичних препаратів. Гомеопатичні Мateria medica та } \\
\text { Repertorium. Критерії відбору симптомів для пошуку ліків } \\
\text { та потенції гомеопатичного препарату }\end{array}$ & 27,39 & 11,1 & 3 & 5 \\
\hline $\begin{array}{l}\text { 6. Сучасні напрямки біологічної медицини. } \\
\text { Гомотоксикологія і антигомотоксичні препарати }\end{array}$ & 14,99 & 6,1 & 3 & 2 \\
\hline \multicolumn{5}{|c|}{ Змістовий модуль 2. Спеиіальна гомеопатія } \\
\hline $\begin{array}{l}\text { 7. Загальні принципи лікування хворих із ГРВІ. Комплексні } \\
\text { препарати для індивідуалізованого лікування хворих з ГРВІ }\end{array}$ & 11,95 & 4,8 & 3 & 2 \\
\hline $\begin{array}{l}\text { 8. Основні гомеопатичні монопрепарати для } \\
\text { індивідуалізованого лікування хворих з ГРВI, } \\
\text { реперторизація індивідуальних симптомів }\end{array}$ & 11,88 & 4,8 & 3 & 2 \\
\hline $\begin{array}{l}\text { 9. Загальні принципи лікування хворих з алергічними } \\
\text { станами. Комплексні препарати для індивідуалізованого } \\
\text { лікування хворих з алергічними станами на прикладі } \\
\text { атопічного дерматиту }\end{array}$ & 16,25 & 6,6 & 3 & 3 \\
\hline $\begin{array}{l}\text { 10. Основні гомеопатичні монопрепарати для } \\
\text { індивідуалізованого лікування хворих з алергічними } \\
\text { станами на прикладі атопічного дерматиту, реперторизація } \\
\text { індивідуальних симптомів }\end{array}$ & 11,59 & 4,7 & 3 & 2 \\
\hline $\begin{array}{l}\text { 11. Загальні принципи лікування хворих із синдромом } \\
\text { вегетативної дистонії. Комплексні препарати для } \\
\text { індивідуалізованого лікування хворих з вегетативною } \\
\text { дистонією невротичного генезу }\end{array}$ & 12,06 & 4,9 & 3 & 2 \\
\hline $\begin{array}{l}\text { 12. Основні гомеопатичні монопрепарати для } \\
\text { індивідуалізованого лікування хворих з вегетативною } \\
\text { дистонією невротичного генезу, реперторизація } \\
\text { індивідуальних симптомів }\end{array}$ & 11,88 & 4,8 & 3 & 2 \\
\hline $\begin{array}{l}\text { 13. Загальні принципи лікування дітей. Найважливіші } \\
\text { комплексні препарати для використання в педіатрії }\end{array}$ & 12,12 & 4,9 & 3 & 2 \\
\hline $\begin{array}{l}\text { 14. Основні гомеопатичні монопрепарати для використання } \\
\text { в педіатричній практиці, реперторизація індивідуальних } \\
\text { симптомів }\end{array}$ & 12,06 & 4,9 & 2 & 2 \\
\hline \multicolumn{3}{|l|}{ Сума годин } & 41 & 41 \\
\hline
\end{tabular}

Висновки: 1. Здійснено експертну оцінку результатів медико-соціологічного дослідження, проведеного шляхом анкетування 83 лікарів-інтернів різних спеціальностей щодо структури тематичного плану курсу за вибором “Основи гомеопатії” для студентів вищих медичних навчальних закладів III-IV рівнів акредитації. Встановлено, що для абсолютної більшості ключових питань існує узгодженість думок респондентів. Показано, що відсутні неважливі для медичної практики запитання.

2. Запропоновано оптимізацію методики оцінювання структури тематичних планів освітніх дисциплін 
шляхом внесення до опитувальника ключових запитань, що вивчаються з кожної теми навчальної дисципліни.

3. На підставі отриманих результатів здійснено проектування оптимального розподілу обсягу академічних годин навчальної дисципліни “Основи гомео-

\section{Лiтература}

1. Кредитно-модульна система викладання курсу “Основи гомеопатії” в НМУ імені О. О. Богомольця / Г. Симоненко, В. Шаповал, О. Головчанський, В. Фадєєв // Рефлексотерапія в Україні: досвід і перспективи : матеріали наук.практ. конф. -К., 2009. - С. 163-167.

2. Лопатинська О. І. Оптимізація підготовки спеціалістів за фахом "Фармація" з гомеопатії та гомеопатичної фармації / О. І. Лопатинська, Т. Г. Калинюк // Наука і соціальні проблеми суспільства: медицина, фармація, біотехнологія : матеріали III Міжнар. наук.-практ. конф. - Х., 2003. Ч. 2. - С. 29-31.

3. Основи гомеопатії. Програма навчальної дисциплі- патії” (курс за вибором) за програмою для студентів вищих медичних навчальних закладів III-IV рівнів акредитації за спеціальностями 7.110101 "Лікувальна справа", 7.110104 “Педіатрія” та 7.110105 “Медико-профілактична справа” між навчальними темами, зважаючи на їхню вагомість для майбутніх лікарів.

ни (курс за вибором) для студентів вищих медичних навчальних закладів III-IV рівнів акредитації. - Київ, 2008. $16 \mathrm{c}$.

4. Громовик Б. П. Аналіз дидактичних питань фармацевтичної освіти : методичні рекомендації / Б. П. Громовик, А. В. Горілик. - Львів : Проблемна комісія “Фармація” МO3 та НАМН України, 2012. - 20 с.

5. Санитарная статистика. Ч. 1: Методика статистического исследования / под ред. И. Случанко. - М., 1981. - 118 с.

6. Калачова I. В. Правова статистика [навч. посіб. для вищ. навч. закл.] / І. В. Калачова, Г. Г. Трофімова. - К. : КНЕУ, 2005.-300c. 